\title{
The Impact of Halal Nutrition on Student Morality
}

\section{Kesan Pemakanan Halal Terhadap Akhlak Pelajar}

\author{
Pg Norwidayawati Pg Metusin ${ }^{*}$ \\ ${ }^{1}$ Fakulti Syariah, Kolej Universiti Perguruan Ugama Seri Begawan (KUPU SB) \\ *Corresponding Author
}

DOI: https://doi.org/10.30880/jstard.2020.02.03.021

Received 30 September 2020; Accepted 30 November 2020; Available online 31 December 2020

\begin{abstract}
The practice of halal diet in daily life is very important in meeting the demands of religion and also daily life based on Halalan Tayyiban. This food selection, if practiced, can certainly have a profound effect on one's morals. This study aims to identify the moral impact of secondary school students in Brunei Darussalam through the practice of halal nutrition in daily life through four elements of morality, namely morality to oneself, morality to parents, morality to teachers and morality to society. This study uses the design of survey research (Explonatory Research) through quantitative method, which is descriptive by providing a questionnaire to 790 Year 9 secondary school students randomly selected. Overall, these descriptive findings indicate that the four moral elements are at a high level, namely (mean $=4.23$, sp $=0.50)$. In conclusion, good morals can be formed through the practice of halal eating, because with halal eating it will form a clean and pure heart. To further strengthen the practice of halal nutrition in students continuously, it is proposed that halal food education be established in secondary schools in Brunei Darussalam through Islamic religious knowledge subjects. Through halal food education, it will further increase the understanding, practice of students on halal food and at the same time make it a culture in their lives when choosing food. Therefore, by adopting halal diet, one will become a healthier person physically, mentally and spiritually.
\end{abstract}

Keywords: Effects, halal nutrition, student morals, halal diet 


\begin{abstract}
Abstrak: Amalan pemakanan halal dalam kehidupan seharian adalah sangat penting dalam memenuhi tuntutan agama dan juga kehidupan seharian yang berasaskan kepada Halalan Tayyiban. Pemilihan makanan ini jika diamalkan setentunya mampu memberi kesan yang mendalam terhadap akhlak seseorang. Kajian ini bertujuan untuk mengenal pasti kesan akhlak pelajar sekolah menengah di Negara Brunei Darussalam melalui amalan pemakanan halal dalam kehidupan seharian melalui empat elemen akhlak, iaitu akhlak kepada diri sendiri, akhlak kepada ibu bapa, akhlak kepada guru dan akhlak kepada masyarakat. Kajian ini menggunakan reka bentuk kajian tinjauan (Explonatory Research) melalui kaedah kuantitatif, iaitu deskriptif dengan memberikan soal selidik kepada 790 orang pelajar sekolah menengah Tahun 9 yang dipilih secara rawak. Secara keseluruhan, dapatan deskriptif ini menunjukkan ke empat-empat elemen akhlak berada pada tahap tinggi, iaitu $(\min =4.23, \mathrm{sp}=0.50)$. Kesimpulannya, akhlak yang baik boleh dibentuk melalui amalan pemakanan halal, kerana dengan pemakanan yang halal itu akan membentuk hati yang bersih dan suci. Bagi mengukuhkan lagi amalan pemakanan halal dalam diri pelajar secara berterusan, maka dicadangkan pendidikan makanan halal diwujudkan di sekolah-sekolah menengah di Negara Brunei Darussalam melalui mata pelajaran pengetahuan ugama Islam. Melalui pendidikan makanan halal itu nanti akan meningkatkan lagi kefahaman, amalan pelajar terhadap pemakanan halal dan sekaligus menjadikannya sebagai budaya dalam kehidupan mereka sewaktu memilih makanan. Justeru itu dengan mengamalkan pemakanan halal, seseorang akan menjadi seorang yang lebih sihat dari segi fizikal, mental dan kerohanian.
\end{abstract}

Kata Kunci: Kesan, nutrisi halal, moral pelajar, diet halal

\title{
1. Pengenalan
}

Akhlak merupakan satu kepercayaan, satu undang-undang atau satu sistem yang berkaitan dengan tindakan manusia sama ada perkara itu baik atau buruk, benar atau salah dari konteks keimanan manusia terhadap Allah Subhanahu Wataala (Ab Halim \& Zarin, 2002). Menurut Zaharah, et al. (2017) pula, akhlak ialah yang boleh diasuh, dididik dan dilatih. Maka penghayatan akhlak itu dapat digambarkan secara langsung melalui kesan luaran manusia itu sendiri (Azhar, 2006, Azhar \& Ab Halim, 2003), kerana akhlak terdiri daripada keadaan jiwa yang mantap dan mampu melakukan sesuatu perbuatan secara semula jadi tanpa perlu berfikir (al Ghazali, 1988).

Sehubungan itu pembentukan akhlak mulia bukanlah merupakan suatu bahagian yang terasing dalam Islam. Ia merupakan salah satu teras atau asas ajaran Islam itu sendiri (Asmawati, 2003, 2005, 2009). Maka dapat disimpulkan di sini, salah satu cara membentuk akhlak mulia adalah dengan menjaga pemakanan. Secara tidak langsung orang yang membentuk akhlak pelajar juga berperanan dalam menjaga pemakanan pelajar.

Hal ini bersesuaian dengan apa yang dinyatakan al-Ghazali (1988) iaitu "Jika makanan yang dimakan itu adalah dijamin halal, maka makanan itu akan membentuk hati yang bersih dan suci, sebaliknya jika makanan yang dimakan itu bercampur dengan benda haram haram ataupun syubhah, maka makanan tersebut akan membentuk hati yang kotor dan keji”. Jelas di sini, makanan yang dimasukkan ke dalam perut itu akan memberikan kesan yang amat besar dalam pembentukan akhlak manusia.

Justeru itu, pemakanan halal perlu diberi perhatian bermula pada peringkat awal kanak-kanak lagi (al-Ghazali, 1988) khususnya dalam melentur jiwa dan akhlak yang lebih baik dan sempurna, kerana anak merupakan amanah daripada Allah Subhanahu Wataala yang wajib dipikul dan dijaga dengan sebaik-baiknya. Anak-anak juga diibaratkan sebagai agen pembangun negara pada masa akan datang. Maka ibu bapa wajib mendidik mereka agar menjadi insan yang soleh, berilmu dan bertaqwa supaya mereka dapat menjadi anak yang soleh. Selain itu, ibu bapa juga perlu memberikan makanan dan minuman yang halal untuk pertumbuhan dan akhlak anak yang lebih sempurna dalam kehidupan mereka sesuai dengan ajaran Islam yang mulia.

\section{Sorotan Karya}

\section{Konsep Pemakanan Halal dalam Islam}

Firman Allah Subhanahu Wataala:

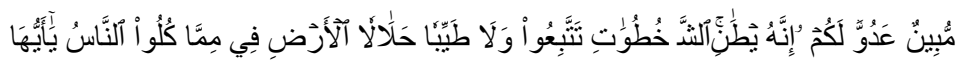

Terjemahan ayat:

"Wahai sekalian manusia! makanlah dari apa yang ada di bumi yang halal lagi baik, dan janganlah kamu ikut jejak langkah syaitan; kerana sesungguhnya syaitan itu ialah musuh yang terang nyata bagi kamu".

(Surah al-Baqarah, 2:168)

Pembahasan tentang pemakanan halal dalam Islam yang berkonsepkan halal lagi baik (ط بـ با حلا ل) banyak dibincangkan oleh para ulama terdahulu dan sekarang, di antaranya ialah Imam al-Razi (1995) menjelaskan pemakanan 
yang disarankan dalam Islam bukan hanya dari aspek kehalalan sahaja tetapi makanan itu hendaklah makanan yang sedap dan sesuai dengan kesihatan tubuh badan manusia. Al-Ghazali (1998) pula mentafsirkan pemakanan yang halal itu diistilahkan sebagai makanan yang baik, tetapi setiap makanan yang baik itu tidak semestinya halal dan boleh dimakan oleh umat Islam. Maka umat Islam perlu berhati-hati mengenainya.

Ibn Kathir (1996, 1998) dan al-Sabuni (1999) keduanya menjelaskan maksud yang sama tentang pengertian pemakanan halal dalam Islam iaitu apa yang telah dihalalkan oleh Allah Subhanahu Wataala. Maka sesuatu yang dihalalkan itu seharuslah bersesuaian dengan keadaan individu-individu tertentu supaya makanan yang diambil tidak mendatangkan kemudaratan pada tubuh badan dan akal fikiran orang yang memakan makanan tersebut.

Al-Qardhawi (1994) pula menjelaskan setiap makanan yang ada di muka bumi ini pada asalnya adalah dibolehkan untuk dimakan asalkan tiada sebarang tanda yang menunjukkan pengharamannya dari segi percampuran dengan benda najis ataupun syubhah seperti mana yang dinyatakan di dalam al-Quran dan hadis Baginda Rasulullah Sallallahu 'Alaihi Wasallam. Maka tidak syak lagi pemakanan dalam Islam yang dijelaskan al-Qardhawi (1994) ini adalah memberi maksud pengambilan pemakanan yang halal lagi baik (ط) d بـ kajian-kajian lepas seperti Luqman (2006) dan Zulkifli (2014).

Zaidan, 'Abd al Karim (2006:148) pula menjelaskan dua aspek utama yang perlu dijaga dalam memastikan makanan yang dimakan itu terhindar daripada sebarang percampuran dengan benda haram, iaitu pertama penjagaan dari aspek kebersihan dan keselamatan makanan agar tidak bercampur dengan benda haram ataupun najis. Kedua boleh mencapai Maqasid Syariah Islamiah yang lima iaitu, Menjaga kesucian agama, jiwa, akal, keturunan dan harta.

Perbincangan di atas jelas menunjukkan pemakanan yang berkonsepkan halal dan baik (b) sangat penting untuk diamalkan bagi setiap umat Islam bagi pembentukan akhlak seseorang (Abdul Azis Dahlan, 1999, Hayati@Habibah \& Khairul Anuar, 2008, Zakiah. et.al, 2011, 2014, Norkumala, 2013, Siti Zanariah et.al, 2014). Melalui pemakanan halal, seseorang itu akan mampu melakukan amalan-amalan soleh dan anggota badan akan mentaati akal (Siti Norlina et al., 2005, Anuar, 1998) dan dapat menambah cahaya iman seseorang dan membuat terkabulnya doa, sementara makanan yang haram dapat menggelapkan hati serta terdindingnya doa (al-Ghazali, 1988).

Justeru itu, setiap umat Islam dituntut agar sentiasa berwara' dalam perkara yang berhubung dengan makanan dan minuman seharian bagi menghindari daripada mengambil benda-benda haram dan syubhah kerana amal perbuatan manusia termasuk doa tidak akan diterima oleh Allah Subhanahu Wataala tanpa mengamalkan pemakanan yang halal lagi baik (al-Ghazali, 1988). Selain itu, pemakanan tersebut bukan hanya untuk keperluan umat Islam semata-mata tetapi bagi menjamin kehidupan manusia keseluruhannya (Saadan Man \& Zainal Abidin, 2014, Persatuan Pengguna Pulau Pinang, 2006).

Sabda Rasulullah Sallallahu 'Alaihi Wasallam:

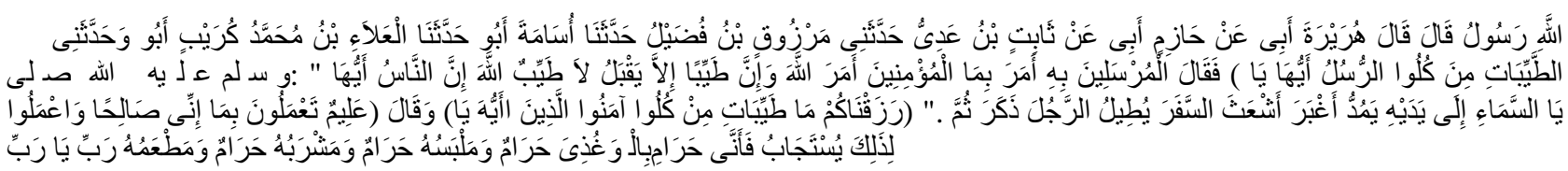

Maksud Hadis:

“Wahai Manusia, sesungguhnya Allah itu baik dan Dia tidak menerima kecuali yang baik. Sesungguhnya Allah memerintahkan kepada orang-orang mukmin sejajar dengan apa yang diperintahkan kepada para raul. Alalh berfirman, "Wahai rasul-rasul, makanlah dari benda-benda yang baik lagi halal dan kerjakanlah amal-amal soleh, sesungguhnya Aku Maha Mengetahui akan apa yang kamu kerjakan" (al Mukminun 23:51) dan "Wahai orang-orang yang beriman! makanlah dari benda-benda yang baik (yang halal) yang telah Kami berikan kepada kamu”(al Baqarah 2:172). Kemudian Rasulullah Sallallahu 'Alaihi Wasallam menyebut tentang seorang lelaki yang menempuh perjalanan yang panjang sehingga berada dalam keadaan lusuh dan berdebu. Lelaki itu menadah tangannya ke langit dan berkata "Ya Tuhan, Ya Tuhan" sedangkan makanannya adalah haram, minumannya haram, pakaiannya haram dan diberi makan yang haram. Bagaimanakah akan dimakbulkan doanya?". baik).

(Riwayat Imam Muslim, no Hadis: 2393, Kitab al-Zakat, bab mengenai sedekah yang diterima daripada usaha yang

\section{Kriteria Pemakanan dalam Islam}

Islam telah meletakkan garis pandu dalam pemilihan makanan. Seorang Muslim perlu memastikan makanan yang

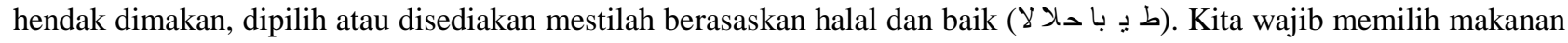
yang halal dan menjauhi makanan yang haram, kerana dengan mengambil makanan yang diharamkan akan menimbulkan kemudharatan kepada kesihatan tubuh badan serta merupakan satu dosa yang dilakukan terhadap Allah Subhanahu Wataala (Khairudin, 2013, al Ghazali, 1988, Panduan Persatuan Pengguna Pulau Pinang, 2006). Antara kriteria pemakanan yang halal dan baik (ط يـ با حلا ل) yang disarankan dalam Islam adalah seperti berikut: 
i. Makanan yang dimakan hendaklah halal, baik dan bersih daripada zat, sumber dan keadaannya kerana makanan yang disarankan tersebut menjamin kesihatan fizikal, spiritual dan mental. Zaman kini terdapat banyak produk halal tetapi tidak bersih atau berkhasiat untuk manusia. Begitu juga ada makanan halal dan berzat tetapi tidak sesuai untuk orang yang berpenyakit.

ii. Makanan yang dimakan hendaklah melalui hasil sembelihan yang sah mengikut syarak, iaitu haiwan yang hendak dimakan itu hendaklah disembelih mengikut cara Islam. Ke semua produk yang terhasil daripada sembelihan tersebut adalah halal dimakan seperti daging, kulit, bulu, minyak, lemak dan tulangnya.

iii. Makanan yang berkhasiat dan berzat untuk proses pembesaran dan kesihatan. Iaitu makanan yang memberi tenaga dan memberi kesihatan tubuh badan.

iv. Makanan yang segar, contohnya sayur-sayuran, buah-buahan atau makanan yang baru dimasak kerana jika memakan makanan yang telah dibekukan dan disimpan begitu lama boleh menyebabkan timbulnya bakteria ke dalam makanan tersebut.

v. Makanan yang asli dan tidak bercampur dengan bahan campuran kimia seperti bahan perasa, pengawet dan pewarna tiruan yang boleh mengurangkan kualiti makanan tersebut.

vi. Makanan yang seimbang dan sesuai dengan keadaan seseorang itu. Iaitu kuantiti pengambilan makanan mengikut faktor umur, jantina, jenis pekerjaan dan keadaan kesihatan seseorang. Seimbang di sini bermaksud seimbang dari segi pengambilan zat makanan seperti karbohidrat, lemak, protein, vitamin, glkos, zat besi, kalsium dan fostat. Kekurangan zat makanan atau ketidakseimbangan boleh mengakibatkan timbulnya pelbagai penyakit.

vii. Makanan yang dimakan adalah tidak berlebihan yang boleh menimbulkan pelbagai penyakit yang merbahaya seperti darah tinggi, lemah jantung, kencing manis dan sebagainya. Makanan yang dimakan secara berlebihan juga boleh mengakibatkan pembaziran dan hal ini dibenci oleh Allah subhanahu wataala kerana orang yang suka membazir adalah mengikut tabiat syaitan (Che Wan Jasimah Wan Mohamed Radzi, 2013, Noorsalwati, 2007, Nazih Hammad, 2004, Jamal Khair \& Noraini, 1997).

\section{Hikmah Memakan Makanan Halal}

Makanan halal sangat penting diamalkan dalam menilai sikap keprihatinan seseorang terhadap tuntutan agama Islam dan juga memenuhi tuntutan hidup yang berasaskan kepada Halalan Tayyiban (Zakiah, et. al, 2011, 2014). Kesan memakan makanan halal ini boleh dilihat melalui perubahan tingkah laku seseorang (Norkumala, 2013) kerana salah satu hikmah memakan makanan halal dapat membersihkan hati seseorang dan hati yang bersih itu akan melahirkan akhlak yang mulia di sisi Allah Subhanahu Wataala dan Rasulnya (Rushidah et al, 2011).

Al-Ghazali (1988) ada menyatakan "Siapa saja yang makan dan minum demi memperoleh ilmu serta amal salih dan bertaqwa kepada Allah Subhanahu Wataala, maka makanan dan minuman yang dimakan adalah dinilai sebagai ibadah". Maka seseorang yang mengaku dirinya bertaqwa kepada Allah Subhanahu Wataala haruslah melakukan suruhan Allah Subhanahu Wataala. Selain itu juga hendaklah memgamalkan pemakanan yang disarankan mengikut ajaran Islam, iaitu dengan mengamalkan pemakanan halal dan kesederhanaan dalam pengambilan makanan dan mengelakkan pembaziran yang diamalkan oleh syaitan.

Justeru itu, dengan mengamalkan pemakanan halal dalam kehidupan seharian, pelajar akan dapat menghasilkan akhlak-akhlak yang baik lagi terpuji yang diperintahkan oleh Allah Subhanahu Wataala dan Rasulnya melalui pembentukan akhlak mulia (ال كري مة الأخ لاق) terhadap diri sendiri dengan mengikut perintah Allah Subhanahu wataala dan menjauhi larangannya, mentaati dan menghormati, ibu bapa, guru dan masyarakat sekeliling. Malah pelajar yang mengamalkan pemakanan halal dalam kehidupan seharian, pasti akan dapat menjadi seorang pelajar yang baik akhlaknya.

\section{Metodologi}

Dalam kajian ini, pengkaji telah menggunakan reka bentuk kaedah tinjauan yang juga dikenali sebagai reka bentuk penyelidikan pengembangan (Exploratory Research). Sebanyak 20 buah sekolah dari keempat-empat daerah dipilih sebagai sampel dalam kajian ini, iaitu seramai 790 orang pelajar termasuk lelaki dan perempuan dengan menggunakan rawak mudah bagi menjawab soal selidik yang telah disediakan.

Item yang terdapat dalam soal selidik ini dikumpul dan diadaptasi daripada kajian lepas serta diubah suai sendiri oleh pengkaji mengikut kesesuaian kajian yang dijalankan di negara ini, iaitu kajian lepas yang berkaitan dengan akhlak ialah kajian Azhar (2006) dan al-Ghazali dalam kitab Ihya 'Ulumuddin mengenai akhlak (1988). Item soal selidik ini dibahagikan kepada dua bahagian, iaitu Bahagian A: Demografi pelajar (9 item) dan Bahagian B: Kesan pemakanan halal dan pengaruhnya terhadap akhlak pelajar (35 item). Manakala Skala Likert digunakan sebagai pengukur kajian untuk menjawab item-item dalam Bahagian B. 


\section{Dapatan Kajian}

Soal selidik ini mengandungi empat komponen akhlak yang pasti dimiliki oleh seorang pelajar Muslim yang mengamalkan pemakanan halal, iaitu berakhlak terhadap diri sendiri, ibu bapa, guru dan masyarakat.

\section{Akhlak Pelajar kepada Diri Sendiri}

Jadual 1 - Dapatan soal selidik akhlak pelajar terhadap diri sendiri

\begin{tabular}{|c|c|c|c|c|c|c|c|c|}
\hline \multirow[t]{2}{*}{ Item } & \multirow[t]{2}{*}{ Pernyataan } & \multicolumn{5}{|c|}{$\begin{array}{l}\text { Frekuensi (f) } \\
\text { Peratus (\%) }\end{array}$} & \multirow[t]{2}{*}{ Min } & \multirow[t]{2}{*}{$\mathbf{S P}$} \\
\hline & & STS & TS & $\mathbf{A S}$ & $\mathbf{S}$ & SS & & \\
\hline EA01 & $\begin{array}{l}\text { Mematuhi perintah Allah dan } \\
\text { Rasulnya }\end{array}$ & $\begin{array}{c}5 \\
(0.6)\end{array}$ & $\begin{array}{c}6 \\
(0.8)\end{array}$ & $\begin{array}{c}86 \\
(10.9)\end{array}$ & $\begin{array}{c}244 \\
(30.9)\end{array}$ & $\begin{array}{c}449 \\
(56.9)\end{array}$ & 4.42 & 0.76 \\
\hline EA02 & $\begin{array}{l}\text { Menjaga peribadatan dengan } \\
\text { sempurna }\end{array}$ & $\begin{array}{l}11 \\
(1.4)\end{array}$ & $\begin{array}{c}34 \\
(4.3)\end{array}$ & $\begin{array}{c}243 \\
(30.8)\end{array}$ & $\begin{array}{c}269 \\
(34.1)\end{array}$ & $\begin{array}{c}233 \\
(29.5)\end{array}$ & 3.85 & 0.93 \\
\hline EA03 & $\begin{array}{l}\text { Bersederhana dalam pengambilan } \\
\text { makanan }\end{array}$ & $\begin{array}{c}12 \\
(1.5)\end{array}$ & $\begin{array}{c}37 \\
(4.7)\end{array}$ & $\begin{array}{c}192 \\
(24.3)\end{array}$ & $\begin{array}{c}327 \\
(41.4)\end{array}$ & $\begin{array}{c}222 \\
(28.1)\end{array}$ & 3.89 & 0.91 \\
\hline EA04 & $\begin{array}{l}\text { Bersifat jujur dalam percakapan dan } \\
\text { perbuatan }\end{array}$ & $\begin{array}{c}6 \\
(0.8)\end{array}$ & $\begin{array}{c}36 \\
(4.6)\end{array}$ & $\begin{array}{c}262 \\
(33.2)\end{array}$ & $\begin{array}{c}280 \\
(35.4)\end{array}$ & $\begin{array}{c}206 \\
(26.1)\end{array}$ & 3.81 & 0.89 \\
\hline EA05 & $\begin{array}{l}\text { Bertaubat dari memakan makanan } \\
\text { yang haram }\end{array}$ & $\begin{array}{c}5 \\
(0.6)\end{array}$ & $\begin{array}{c}6 \\
(0.8)\end{array}$ & $\begin{array}{c}41 \\
(5.2)\end{array}$ & $\begin{array}{c}96 \\
(12.2)\end{array}$ & $\begin{array}{c}642 \\
(81.3)\end{array}$ & 4.02 & 0.89 \\
\hline EA06 & Bersyukur dengan makanan yang ada & $\begin{array}{c}4 \\
(0.5)\end{array}$ & $\begin{array}{c}6 \\
(0.8)\end{array}$ & $\begin{array}{c}103 \\
(13.0)\end{array}$ & $\begin{array}{c}264 \\
(33.4)\end{array}$ & $\begin{array}{c}413 \\
(52.3)\end{array}$ & 4.36 & 0.77 \\
\hline EA07 & Tabah menghadapi musibah & $\begin{array}{c}5 \\
(0.6)\end{array}$ & $\begin{array}{c}16 \\
(2.0)\end{array}$ & $\begin{array}{c}150 \\
(19.0)\end{array}$ & $\begin{array}{c}283 \\
(35.8)\end{array}$ & $\begin{array}{c}336 \\
(42.5)\end{array}$ & 4.17 & 0.85 \\
\hline EA08 & Menjauhi makanan syubhah & $\begin{array}{c}7 \\
(0.9)\end{array}$ & $\begin{array}{c}18 \\
(2.3)\end{array}$ & $\begin{array}{c}210 \\
(26.6)\end{array}$ & $\begin{array}{c}267 \\
(33.8)\end{array}$ & $\begin{array}{c}288 \\
(36.5)\end{array}$ & 4.72 & 0.65 \\
\hline
\end{tabular}

Nilai Min Keseluruhan

4.150 .59

Dapatan kajian menunjukkan bahawa min bagi keseluruhan item akhlak pelajar terhadap diri sendiri yang berada pada tahap yang tinggi ialah "Menjauhi makanan syubhah" (EA08, min=4.72, sp=0.65), diikuti selepas itu "Mematuhi perintah Allah dan Rasulnya" (EA01, $\min =4.42, \mathrm{sp}=0.76)$, "Bersyukur dengan makanan yang sedia ada" (EA06, $\min =4.36 \mathrm{sp}=0.77$ ), "Tabah menghadapi musibah" (EA07, min=4.17, $\mathrm{sp}=0.85)$, "Bertaubat dari memakan makanan yang haram" (EA05, min=4.02, sp=0.89), "Sederhana dalam pengambilan makanan" (EA03, min=3.89, sp=0.91), "Menjaga peribadatan dengan sempurna" (EA02, $\min =3.85, \mathrm{sp}=0.93$ ) dan yang terakhir "Bersifat jujur dalam percakapan dan perbuatan (EA04, min=3.81, sp=0.89). Secara keseluruhan, data yang dianalisis ini menunjukkan bahawa item akhlak pelajar terhadap diri sendiri melalui amalan pemakanan halal yang mendapat min yang tinggi, ialah pelajar sentiasa mentaati perintah Allah Subhanahu Wataala dengan menjauhi daripada memakan makanan yang syubhah.

\section{Akhlak Pelajar kepada Ibu Bapa}

Jadual 2 - Dapatan soal selidik akhlak pelajar terhadap ibu bapa

\begin{tabular}{|c|c|c|c|c|c|c|c|c|}
\hline \multirow[t]{2}{*}{ Item } & \multirow[t]{2}{*}{ Pernyataan } & \multicolumn{5}{|c|}{$\begin{array}{l}\text { Frekuensi (f) } \\
\text { Peratus (\%) }\end{array}$} & \multirow[t]{2}{*}{ Min } & \multirow[t]{2}{*}{ SP } \\
\hline & & STS & TS & $\mathrm{AS}$ & $\mathrm{S}$ & SS & & \\
\hline EB01 & Mentaati perintah ibu bapa & $\begin{array}{c}3 \\
(0.4)\end{array}$ & $\begin{array}{c}2 \\
(0.3)\end{array}$ & $\begin{array}{c}83 \\
(10.5)\end{array}$ & $\begin{array}{c}234 \\
(29.6)\end{array}$ & $\begin{array}{c}468 \\
(59.2)\end{array}$ & 4.47 & 0.72 \\
\hline EB02 & Bersifat jujur dengan ibu bapa & $\begin{array}{c}4 \\
(0.5)\end{array}$ & $\begin{array}{c}7 \\
(0.9)\end{array}$ & $\begin{array}{c}143 \\
(18.1)\end{array}$ & $\begin{array}{c}279 \\
(35.3)\end{array}$ & $\begin{array}{c}357 \\
(45.2)\end{array}$ & 4.23 & 0.81 \\
\hline EB03 & Berlemah lembut dengan ibu bapa & $\begin{array}{c}2 \\
(0.3)\end{array}$ & $\begin{array}{c}14 \\
(1.8)\end{array}$ & $\begin{array}{c}137 \\
(17.3)\end{array}$ & $\begin{array}{c}274 \\
(34.7)\end{array}$ & $\begin{array}{c}363 \\
(45.9)\end{array}$ & 4.24 & 0.81 \\
\hline EB04 & $\begin{array}{l}\text { Membantu ibu bapa dalam setiap } \\
\text { urusan }\end{array}$ & $\begin{array}{c}3 \\
(0.4)\end{array}$ & $\begin{array}{c}13 \\
(1.6)\end{array}$ & $\begin{array}{c}150 \\
(19.0)\end{array}$ & $\begin{array}{c}274 \\
(34.7)\end{array}$ & $\begin{array}{c}350 \\
(44.3)\end{array}$ & 4.20 & 0.83 \\
\hline EB05 & Mendoakan kesihatan ibu bapa & $\begin{array}{c}1 \\
(0.1)\end{array}$ & $\begin{array}{c}8 \\
(1.0)\end{array}$ & $\begin{array}{c}100 \\
(12.7)\end{array}$ & $\begin{array}{c}211 \\
(26.7)\end{array}$ & $\begin{array}{c}470 \\
(59.5)\end{array}$ & 4.44 & 0.75 \\
\hline EB06 & Menjaga ibu bapa ketika mereka sakit & $\begin{array}{c}1 \\
(0.1)\end{array}$ & $\begin{array}{c}8 \\
(1.0)\end{array}$ & $\begin{array}{c}94 \\
(11.9)\end{array}$ & $\begin{array}{c}240 \\
(30.4)\end{array}$ & $\begin{array}{c}447 \\
(56.6)\end{array}$ & 4.42 & 0.74 \\
\hline
\end{tabular}




\begin{tabular}{|c|c|c|c|c|c|c|c|c|}
\hline EB07 & Mendengar nasihat ibu bapa & $\begin{array}{c}1 \\
(0.1)\end{array}$ & $\begin{array}{c}10 \\
(1.3)\end{array}$ & $\begin{array}{c}97 \\
(12.3)\end{array}$ & $\begin{array}{c}229 \\
(29.0)\end{array}$ & $\begin{array}{c}453 \\
(57.3)\end{array}$ & 4.42 & 0.76 \\
\hline EB08 & Berbuat baik terhadap ibu bapa & $\begin{array}{c}4 \\
(0.5)\end{array}$ & $\begin{array}{c}8 \\
(1.0)\end{array}$ & $\begin{array}{c}72 \\
(9.1)\end{array}$ & $\begin{array}{c}246 \\
(31.1)\end{array}$ & $\begin{array}{c}460 \\
(58.2)\end{array}$ & 4.45 & 0.74 \\
\hline
\end{tabular}

Dapatan kajian menunjukkan bahawa min bagi keseluruhan item akhlak pelajar terhadap ibu bapa yang berada pada tahap yang tinggi ialah "Mentaati perintah ibu bapa" (EB01, $\min =4.47, \mathrm{sp}=0.72)$, selepas itu disusuli dengan item "Berbuat baik kepada ibu bapa" (EB08, min=4.45, sp=0.74), "Mendoakan kesihatan ibu bapa" (EB05, min=4.44, $\mathrm{sp}=0.75$ ), "Menjaga ibu bapa ketika mereka sakit" (EB06, min=4.42 sp=0.74), "Mendengar nasihat ibu bapa" (EB07, $\min =4.42, \mathrm{sp}=0.76$ ), "Berlemah lembut dengan ibu bapa" (EB03, $\min =4.24, \mathrm{sp}=0.81)$, "Bersifat jujur kepada ibu bapa" (EB02, $\min =4.23, \mathrm{sp}=0.81$ ) dan yang terakhir "Membantu ibu bapa dalam setiap urusan" (EB04, $\min =4.20, \mathrm{sp}=0.83$ ). Secara keseluruhan, data yang dianalisis ini menunjukkan bahawa item akhlak pelajar terhadap ibu bapa melalui amalan pemakanan halal yang mendapat nilai min yang tinggi ialah pelajar sentiasa mentaati perintah ibu bapa dan berbuat baik kepada keduanya yang merupakan item yang mendapat min yang tinggi.

\section{Akhlak Pelajar kepada Guru}

Jadual 3 - Dapatan soal selidik akhlak pelajar terhadap guru

\begin{tabular}{llccccccc}
\hline Item & \multicolumn{1}{c}{ Pernyataan } & \multicolumn{7}{c}{ Frekuensi (f) } \\
& & Peratus (\%) & Min & SP \\
& STS & TS & AS & S & SS & & \\
EC01 & Mentaati perintah guru & 3 & 6 & 94 & 266 & 421 & 4.38 & 0.75 \\
& & $(0.4)$ & $(0.8)$ & $(11.9)$ & $(33.7)$ & $(53.3)$ & & \\
EC02 & Menghormati guru & 1 & 4 & 82 & 271 & 432 & 4.42 & 0.70 \\
& & $(0.1)$ & $(0.5)$ & $(10.4)$ & $(34.3)$ & $(54.7)$ & & \\
EC03 & Mendengar nasihat guru & 1 & 5 & 84 & 275 & 425 & 4.41 & 0.71 \\
& & $(0.1)$ & $(0.6)$ & $(10.6)$ & $(34.8)$ & $(53.8)$ & & \\
EC04 & Menegur guru apabila berjumpa & 4 & 12 & 177 & 270 & 327 & 4.14 & 0.85 \\
& & $(0.5)$ & $(1.5)$ & $(22.4)$ & $(34.2)$ & $(41.4)$ & & \\
EC05 & Menjadikan guru sebagai role & 6 & 28 & 213 & 263 & 280 & 3.99 & 0.91 \\
& model & $(0.8)$ & $(3.5)$ & $(27.0)$ & $(33.3)$ & $(35.4)$ & & \\
EC06 & Menyelesaikan tugasan sekolah & 2 & 16 & 173 & 285 & 313 & 4.19 & 1.99 \\
& yang diberikan guru & $(0.3)$ & $(2.0)$ & $(21.9)$ & $(36.1)$ & $(39.6)$ & & \\
EC07 & Mendoakan kesihatan guru & 10 & 22 & 201 & 267 & 290 & 4.01 & 0.92 \\
& & $(1.3)$ & $(2.8)$ & $(25.4)$ & $(33.8)$ & $(36.7)$ & & \\
EC08 & Meminta nasihat guru & 8 & 38 & 181 & 263 & 300 & 4.02 & 0.94 \\
& & $(1.0)$ & $(4.8)$ & $(22.9)$ & $(33.3)$ & $(38.0)$ & & \\
EC09 & Membantu guru ketika & 3 & 13 & 124 & 269 & 381 & 4.28 & 0.81 \\
& diperlukan & $(0.4)$ & $(1.6)$ & $(15.7)$ & $(34.1)$ & $(48.2)$ & & \\
\hline & Nilai Min Keseluruhan & & & & & & $\mathbf{4} .19$ & $\mathbf{0 . 6 2}$
\end{tabular}

Dapatan kajian yang menunjukkan min bagi keseluruhan item akhlak pelajar terhadap guru pada tahap yang tinggi ialah "Menghormati guru" (EC02, $\min =4.42, \mathrm{sp}=0.70)$, selepas itu disusuli dengan item "Mendengar nasihat guru" $(\mathrm{EC} 03, \mathrm{~min}=4.41, \mathrm{sp}=0.71)$, "Mentaati perintah guru" (EC01, min=4.38, sp=0.75), "Membantu guru ketika diperlukan" (EC09, min=4.28, sp=0.81), "Menyelesaikan tugasan sekolah yang diberikan guru" (EC06, min=4.19 sp=1.99), "Menegur guru apabila berjumpa (EC04, $\min =4.14, \mathrm{sp}=0.85)$, "Meminta nasihat guru" (EC08, min=4.02, sp=0.94), "Mendoakan kesihatan guru" (EC07, $\min =4.01, \mathrm{sp}=0.92)$ dan yang terakhir "Menjadikan guru sebagai role model" (EC05, min=3.99, sp=0.91). Secara keseluruhan, data yang dianalisis ini menunjukkan bahawa item akhlak pelajar terhadap guru melalui amalan pemakanan halal yang mendapat nilai min yang tinggi ialah pelajar sentiasa menghormati guru. 


\section{Akhlak Pelajar terhadap Masyarakat}

Jadual 4 - Dapatan soal selidik akhlak pelajar terhadap masyarakat

\begin{tabular}{|c|c|c|c|c|c|c|c|c|}
\hline \multirow[t]{2}{*}{ Item } & \multirow[t]{2}{*}{ Pernyataan } & \multicolumn{5}{|c|}{$\begin{array}{l}\text { Frekuensi (f) } \\
\text { Peratus (\%) }\end{array}$} & \multirow[t]{2}{*}{ Min } & \multirow[t]{2}{*}{ SP } \\
\hline & & STS & $\mathrm{TS}$ & AS & $\mathrm{S}$ & SS & & \\
\hline ED01 & $\begin{array}{l}\text { Mengucap salam apabila berjumpa } \\
\text { saudara Islam }\end{array}$ & $\begin{array}{c}7 \\
(0.9)\end{array}$ & $\begin{array}{l}20 \\
(2.5)\end{array}$ & $\begin{array}{c}167 \\
(21.1)\end{array}$ & $\begin{array}{c}285 \\
(36.1)\end{array}$ & $\begin{array}{c}311 \\
(39.4)\end{array}$ & 4.10 & 0.88 \\
\hline ED02 & $\begin{array}{l}\text { Menghormati saudara Islam dan } \\
\text { bukan Islam }\end{array}$ & $\begin{array}{c}3 \\
(0.4)\end{array}$ & $\begin{array}{c}3 \\
(0.4)\end{array}$ & $\begin{array}{l}74 \\
(9.4)\end{array}$ & $\begin{array}{c}290 \\
(36.7)\end{array}$ & $\begin{array}{c}420 \\
(53.2)\end{array}$ & 4.41 & 0.70 \\
\hline ED03 & $\begin{array}{l}\text { Membantu saudara /kawan yang } \\
\text { susah }\end{array}$ & $\begin{array}{c}2 \\
(0.3)\end{array}$ & $\begin{array}{c}7 \\
(0.9)\end{array}$ & $\begin{array}{c}170 \\
(21.5)\end{array}$ & $\begin{array}{c}314 \\
(39.7)\end{array}$ & $\begin{array}{c}297 \\
(37.6)\end{array}$ & 4.13 & 0.79 \\
\hline ED04 & $\begin{array}{l}\text { Menziarahi saudara /kawan yang } \\
\text { sakit }\end{array}$ & $\begin{array}{c}8 \\
(1.0)\end{array}$ & $\begin{array}{c}7 \\
(0.9)\end{array}$ & $\begin{array}{c}169 \\
(21.4)\end{array}$ & $\begin{array}{c}309 \\
(39.1)\end{array}$ & $\begin{array}{c}297 \\
(37.6)\end{array}$ & 4.11 & 0.83 \\
\hline ED05 & Berlaku adil sesama manusia & $\begin{array}{c}3 \\
(0.4)\end{array}$ & $\begin{array}{c}12 \\
(1.5)\end{array}$ & $\begin{array}{c}158 \\
(20.0)\end{array}$ & $\begin{array}{c}308 \\
(39.0)\end{array}$ & $\begin{array}{c}309 \\
(39.1)\end{array}$ & 4.14 & 0.81 \\
\hline ED06 & $\begin{array}{l}\text { Bersopan santun dengan saudara } \\
\text { yang lebih tua }\end{array}$ & $\begin{array}{c}3 \\
(0.4)\end{array}$ & $\begin{array}{c}3 \\
(0.4)\end{array}$ & $\begin{array}{l}73 \\
(9.2)\end{array}$ & $\begin{array}{c}229 \\
(29.0)\end{array}$ & $\begin{array}{c}482 \\
(61.0)\end{array}$ & 4.49 & 0.70 \\
\hline ED07 & Menepati janji sesama manusia & $\begin{array}{c}2 \\
(0.3)\end{array}$ & $\begin{array}{c}16 \\
(2.0)\end{array}$ & $\begin{array}{c}193 \\
(24.4)\end{array}$ & $\begin{array}{c}292 \\
(37.0)\end{array}$ & $\begin{array}{c}287 \\
(36.3)\end{array}$ & 4.07 & 0.84 \\
\hline ED08 & $\begin{array}{l}\text { Menghindari pertengkaran sesama } \\
\text { manusia }\end{array}$ & $\begin{array}{c}5 \\
(0.6)\end{array}$ & $\begin{array}{c}14 \\
(1.8)\end{array}$ & $\begin{array}{c}150 \\
(19.0)\end{array}$ & $\begin{array}{c}291 \\
(36.8)\end{array}$ & $\begin{array}{c}330 \\
(41.8)\end{array}$ & 4.17 & 0.84 \\
\hline ED09 & Berbuat baik sesama manusia & $\begin{array}{c}4 \\
(0.5)\end{array}$ & $\begin{array}{c}6 \\
(0.8)\end{array}$ & $\begin{array}{c}114 \\
(14.4)\end{array}$ & $\begin{array}{c}295 \\
(37.3)\end{array}$ & $\begin{array}{c}371 \\
(47.0)\end{array}$ & 4.29 & 0.77 \\
\hline ED10 & $\begin{array}{l}\text { Bergaul/berkawan dengan sesama } \\
\text { manusia }\end{array}$ & $\begin{array}{c}5 \\
(0.6)\end{array}$ & $\begin{array}{c}14 \\
(1.8)\end{array}$ & $\begin{array}{c}103 \\
(13.0)\end{array}$ & $\begin{array}{c}255 \\
(32.3)\end{array}$ & $\begin{array}{c}413 \\
(52.3)\end{array}$ & 4.33 & 0.81 \\
\hline & Nilai Min Keseluruhan & & & & & & 4.22 & 0.59 \\
\hline
\end{tabular}

Dapatan kajian yang menunjukkan item akhlak pelajar terhadap masyarakat yang berada pada tahap yang tinggi ialah "Bersopan santun dengan saudara yang lebih tua" (ED06, min=4.49 sp=0.70), setelah itu disusuli dengan item "Menghormati saudara Islam dan bukan Islam" (ED02, min=4.41, sp=0.70), Bergaul / berkawan dengan sesama manusia" (ED10, $\min =4.33, \mathrm{sp}=0.81$ ), "Berbuat baik sesama manusia (ED09, min=4.29, sp=0.77), "Menghindari pertengkaran sesama manusia" (ED08, $\min =4.17, \mathrm{sp}=0.84)$, "Berlaku adil sesama manusia" (ED05, min=4.14, $\mathrm{sp}=0.81$ ), "Membantu saudara/kawan yang susah" (ED03, min=4.13, sp=0.79), "Menziarahi saudara/ kawan yang sakit" (ED04, min=4.11, sp=0.83), "Mengucap salam apabila berjumpa dengan saudara Islam" (ED01, min=4.10, $\mathrm{sp}=0.88$ ) dan item yang terakhir ialah "Menepati janji sesama manusia" (ED07, min=4.07, $\mathrm{sp}=0.84$ ). Secara keseluruhan, dapatan kajian ini menunjukkan item akhlak pelajar terhadap masyarakat melalui amalan pemakanan halal yang mendapat min yang tinggi ialah pelajar sentiasa menghormati dan bersopan santun dengan orang yang lebih tua dengan melakukan kebaikan dan menjauhi segala larangan.

Setelah menghuraikan setiap dapatan mengikut komponen item akhlak pelajar melalui pemakanan halal, maka huraian nilai keseluruhan min dan sisihan piawaian bagi akhlak pelajar melalui pemakanan halal dipaparkan dalam Jadual 5 berikut.

Jadual 5 - Nilai min dan sisihan piawaian item akhlak pelajar melalui amalan pemakanan halal secara keseluruhan

\begin{tabular}{clccc}
\hline Bil & Pembentukan Akhlak & Min & SP & Indikator Nilai Min \\
\hline 1 & Akhlak Terhadap Diri sendiri & 4.15 & 0.59 & Tinggi \\
2 & Akhlak Terhadap Ibu bapa & 4.35 & 0.59 & Tinggi \\
3 & Akhlak Terhadap Guru & 4.19 & 0.62 & Tinggi \\
4 & Akhlak Terhadap Masyarakat & 4.22 & 0.59 & Tinggi \\
\hline & Nilai Min Keseluruhan & $\mathbf{4 . 2 3}$ & $\mathbf{0 . 5 0}$ & Tinggi
\end{tabular}

Secara umumnya, dapatan kajian mendapati nilai min bagi item akhlak pelajar melalui amalan pemakanan halal secara keseluruhan berada pada tahap yang tinggi, iaitu $(\min =4.23, \mathrm{sp}=0.50)$. Analisis dapatan kajian menunjukkan pembentukan akhlak pelajar yang mulia dapat dibentuk melalui amalan pemakanan halal, iaitu pelajar berakhlak mulia kepada ibu bapa, masyarakat, guru dan diri sendiri. Pelajar juga akan sentiasa mentaati perintah Allah Subhanahu Wataala dan menjauhi segala larangannya. Selain itu, pelajar juga sentiasa berkelakuan baik dengan orang sekeliling mereka. Huraian perbandingan nilai keseluruhan min bagi item akhlak pelajar melalui amalan pemakanan halal juga dipaparkan dalam Rajah 1 berikut. 


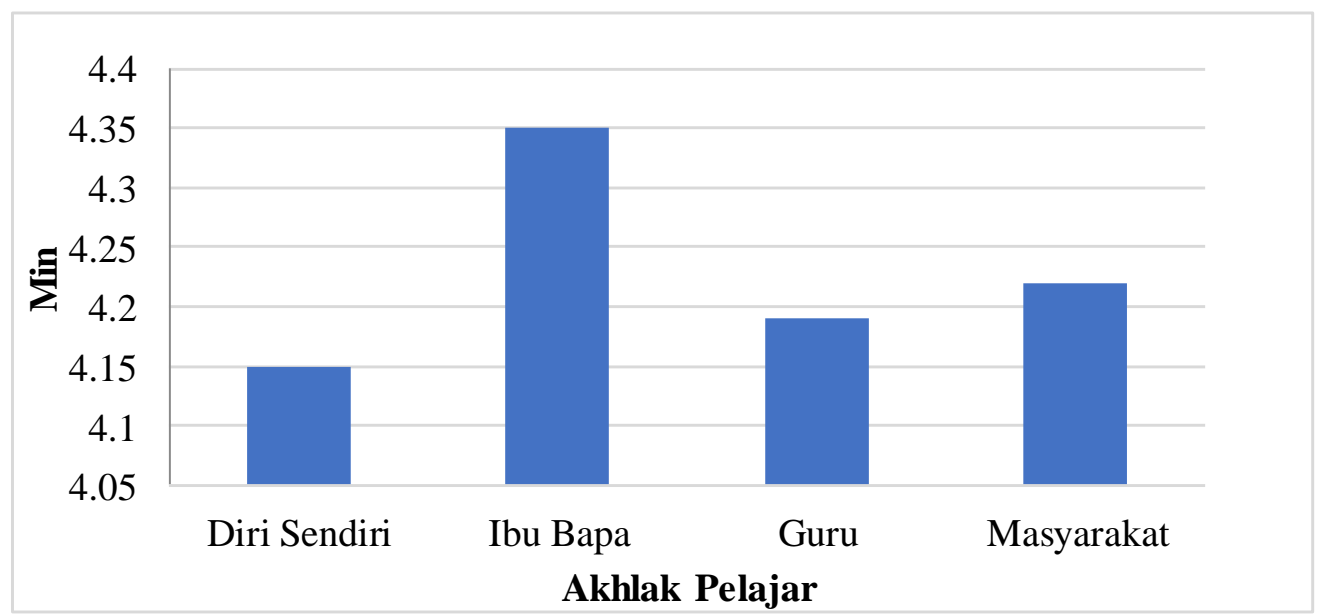

Rajah 1 - Perbandingan nilai keseluruhan min akhlak pelajar melalui amalan pemakanan halal

\section{Dapatan dan Cadangan Kajian}

Secara keseluruhan, dapatan kajian ini mendapati akhlak pelajar terhadap diri sendiri, ibu bapa, para guru dan masyarakat berada pada tahap yang tinggi. Dapatan ini menunjukkan akhlak yang baik boleh dibentuk melalui amalan pemakanan halal. Melalui amalan pemakanan halal, pelajar dapat menunjukkan sifat seorang Muslim yang sejati seperti yang telah digariskan dalam Islam bagi menjamin kehormanian hidup sesama manusia dan mewujudkan kharmonian dalam masyarakat, negara dan berkeluarga, contohnya menghormati dan mentaati perintah ibu bapa, menghormati dan mengikut arahan guru dari masa ke semasa serta mengamalkan sifat bersopan santun dan menghormati orang yang lebih tua di sekeliling pelajar.

Hal ini bersesuaian dengan kajian Muslihuddin Syah (2013) yang menyatakan tahap keprihatinan masyarakat Islam di Negara Brunei Darussalam berada pada tahap yang tinggi. Dikukuhkan lagi dengan kajian Muslichah et al. (2015) yang menyatakan faktor agama merupakan faktor utama dalam mempengaruhi pemilihan makanan halal di negara ini. Ini kerana Negara Brunei Darussalam yang dikenali sebagai negara zikir sangat menekankan dan menitikberatkan pemakanan halal di negara ini, maka secara tidak langsung, masyarakat di negara ini khususnya para ibu bapa hampir keseluruhannya juga pasti menerapkan amalan pemakanan halal kepada anak-anak mereka di rumah.

Pembentukan akhlak pelajar yang tinggi ini juga bersesuaian dengan kenyataan Ab Aziz Yusof (2014) yang menyatakan ketinggian akhlak seseorang itu akan menjadikan dirinya bersedia untuk lima perkara, iaitu i) memberi khidmat bakti kepada manusia untuk mendapatkan keredaan daripada Allah Subhanahu Wataala, ii) membuat pengakuan bahawa mereka adalah hamba Allah dan khalifah Allah yang mengakui bahawa segala sumber yang diberikan adalah kurniaan daripada Allah Subhanahu Wataala, iii) memastikan segala tindakan dan keputusan yang diambil merupakan sebahagian ibadah kepada Allah Subhanahu Wataala, iv) membina benteng dalam diri yang berperanan sebagai pendinding yang akan mengelakkan daripada melakukan sesuatu yang boleh menyebabkan kemurkaan Allah Subhanahu Wataala dan v) melawan hawa nafsu daripada terus merosakkan keimanan terhadap Allah Subhanahu Wataala.

Dapatan kajian ini dapat memberi gambaran bahawa pengajaran dan pembelajaran pendidikan makanan halal sangat penting untuk dilaksanakan di sekolah-sekolah menengah di Negara Brunei Darussalam bagi mengukuhkan kefahaman dan amalan pelajar terhadap pemakanan halal dan seterusnya memberi impak yang besar dalam pembentukan akhlak mulia pelajar (الأخلاق الكريمة) selaras dengan ajaran agama Islam. Melalui pendidikan makanan halal yang akan dilaksanakan secara kompleks dan sistematik di bilik-bilik darjah itu nanti, akan dapat diaplikasikan dalam kehidupan pelajar dengan lebih berkesan sehingga dapat melahirkan pelajar yang berakhlak mulia dengan menjaga permakanan seharian seperti yang disarankan dalam agama Islam. Maka dicadangkan pendidikan makanan halal diwujudkan dalam mengukuhkan kefahaman dan amalan pemakanan halal sebagai budaya dalam kehidupan seharian seperti dalam Rajah 2 berikut. 


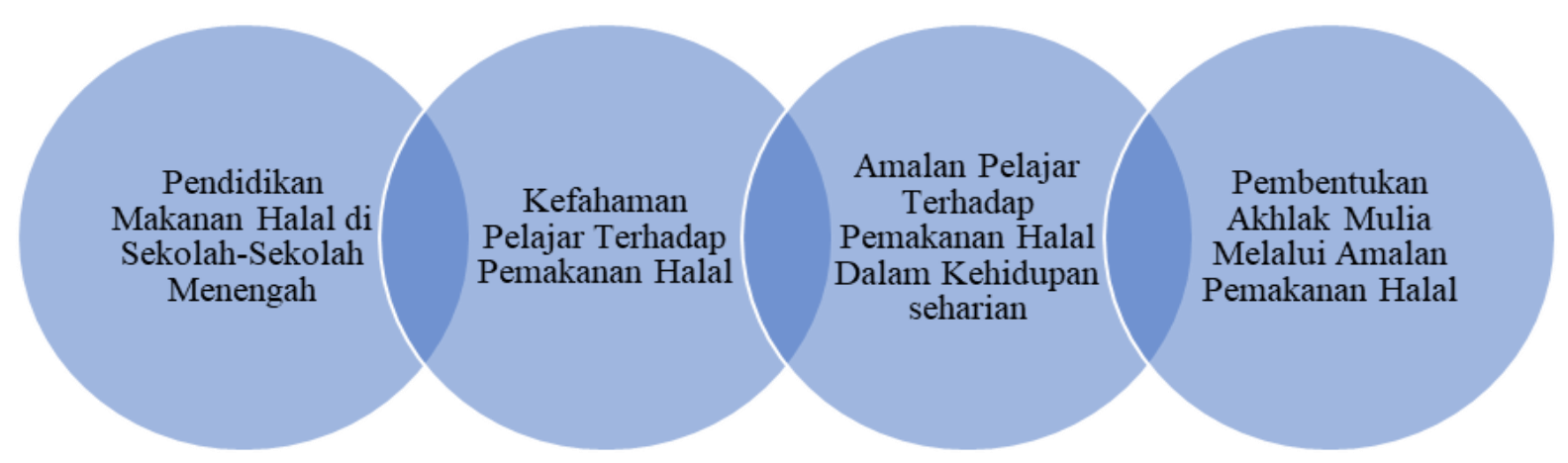

Rajah 2 - Cadangan pendidikan makanan halal dalam mempengaruhi akhlak mulia pelajar melalui kefahaman dan amalan pemakanan halal

\section{Kesimpulan}

Penjagaan makanan merupakan salah satu perkara yang ditekankan dalam Islam bagi mencapai kecemerlangan hidup di dunia dan di akhirat. Pemakanan yang halal dan baik bukan hanya memberikan kesihatan tubuh badan kepada orang yang memakannya tetapi juga melalui pemakanan juga boleh mempengaruhi tingkah laku dan akhlak seseorang.

\section{Penghargaan}

Penulis ingin mengucapkan terima kasih kepada Fakulti Syariah, Kolej Universiti Perguruan Ugama Seri Begawan (KUPU SB)atas bantuan dan maklumat yang diberikan untuk memastikan kejayaan kajian ini.

\section{References}

[1] Mushaf Brunei Darussalam dan Terjemahannya. (2014). Negara Brunei Darussalam: Pusat Da'wah Islamiah

[2] Ab Aziz Yusof. (2014). Pengurusan Pendidikan Islam. Mekanisme Transformasi Ummah. Kuala Lumpur: Dewan Bahasa dan Pustaka

[3] Ab Halim Tamuri \& Zarin Ismail. (2002). Pendidikan Etika Dalam KBSM: Persepsi Pelajar Terhadap Konsep Etika. Prosiding Wacana Pendidikan Islam (Siri 1). Bangi: Fakulti Pendidikan. Universiti Kebangsaan Malaysia, hlmn. 120-134

[4] Abdul Azis Dahlan. (1999). Ensikopedia Hukum Islam. Edisi ke-3. Jakarta: Ictiar Baru Van Hoeve

[5] Al-Ghazali, al-Imam Abu Hamid Muhammad ibn al-Ghazali. (1988). Ihya Ulum al-Din. Jil 1-5. Misr: alMaktabah al-Taufiqiyyah

[6] Al-Sabuni, Muhammad Ali. (1999). Zawal al-Bayan Tafsir Ayat al-Ahkam min al-Quran. Jilid 1. Qaherah: Dar al- Sabuni

[7] Al-Qaradhawi, Yusuf. (1994). al- Halal wa al- Haram fi al-Islami. Jilid 11. Kaherah: Maktabah Wahbah

[8] Al-Razi, al Imam Muhammad. (1995). Tafsir al-Fakhrur Razi: al-Musytahar bit Tafsir al-Kabir wa Mafateeh al Ghaib. Jilid 3. Beirut: Dar al-Fikr

[9] Anuar Abu Bakar. (1998). Pengaruh Pemakanan Terhadap Rohani \& Jasmani. Johor Bahru: Percetakan Nasional Malaysia Berhad

[10] Asmawati Suhid. (2009). Pendidikan Akhlak dan Adab Islam: Konsep dan Amalan. Siri Pengajian dan Pendidikan Utusan, Utusan Publication \& Distributors Sdn. Bhd

[11] Azhar Ahmad. (2006). Strategi Pembelajaran Pengaturan Kendiri Pendidikan Islam dan Penghayatan Akhlak Pelajar Sekolah Menengah di Sarawak. Tesis Dr. Falsafah. Bangi: Fakulti Pengajian Islam, Universiti Kebangsaan Malaysia

[12] Azhar Ahmad \& Ab Halim Tamuri. (2003). Pembelajaran Pengaturan Kendiri dalam Pendidikan Islam KBSM: Kerangka Konseptual dan Prospek Penyelidikan. Prosiding Wacana Pendidikan Islam (siri 3). Bangi: Fakulti Pendidikan, Universiti Kebangsaan Malaysia

[13] Che Wan Jasimah Wan Mohamed Radzi. (2013). Makanan Halal, Makanan Sihat? dalam Pemakanan Yang Sihat Menurut Perspektif Islam. Kuala Lumpur Malaysia: MPH Group Printing (M) Sdn Bhd

[14] Fatwa Mufti Kerajaan. (2007). Isu-Isu Produk Halal. Jabatan Mufti Kerajaan. Selangor Darul Ehsan : Ar-Risalah Product Sdn. Bhd

[15] Hayati@ Habibah Abdul Talib \& Khairul Anuar Mohd Ali. (2008). Aspek Kualiti, Keselamatan dan Kesihatan di Kalangan PKS Makanan: Satu Sorotan Kajian. Jurnal Teknologi, 49E:65-79. Universiti Teknologi Malaysia

[16] Ibn Kathir, 'Imad al-Din Abu al-Fida' al-Hafiz Ismail bin Kathir. (1998). Tafsir Ibn Kathir. Jilid 1, Mesir: Dar alKalimah

[17] Ibn Kathir, 'Imad al-Din Abu al-Fida' al-Hafiz Ismail bin Kathir (1996). Tafsir al-Quran al-Azim. Jilid 2. Beirut : Maktabah al-Asriyyah 
[18] Jamal Khair Hashim \& Noraini Mohd Othman. (1999). Bahan Kimia dalam Makanan Kita. Edisi ke-2. Kuala Lumpur: Dewan Bahasa dan Pustaka

[19] Khairuddin Shaary. (2013). Halalan Thayyiban Amalan Rukhsah dalam Pemakanan. Kuala Lumpur: Telaga Biru Sdn Bhd

[20] Luqman Abdullah et al. (2006). Konsep Halalan Tayyiba dalam Makanan dan Implikasinya terhadap Kesempurnaan Ibadah. Kertas Seminar Kebangsaan Produk Halal Makanan dan Barang Gunaan Islam. Universiti Sains Malaysia. 13-14 Julai

[21] Mohammad Muslihuddin Syah Mustafa. (2013). Keprihatinan Masyarakat Islam terhadap Makanan Halal di Negara Brunei Darussalam. Kertas kerja Konferensi Antarabangsa Islam Borneo VI, anjuran Pusat Penyelidikan dan Pengembangan Islam Borneo (PPIB), UITM Sarawak, 18-19 September

[22] Muslichah Mohammad Machali, Rose Abdullah \& Ahmad Lutfi Abdul Razak. (2015). The Effect of Halal Foods Awareness on Purchase Decision with Religiosity as a Moderating Variable: A Study at Higher Education Institutions in Brunei Darussalam. Presentation Paper. Faculty of Business and Management Sciences. Sultan Sharif Ali Islamic University. Negara Brunei Darussalam

[23] Muslim, Abu al-Husin Muslim ibn al-Hajjaj al-Qusyairi an-Naisaburi. (t.th). Sahih Muslim. Beirut: Dar al-Afaq al-Jadidah, dar al-Jil Beirut

[24] Norkumala Awang. (2013). Pemakanan Yang Sihat Menurut Perspektif Islam. Kuala Lumpur: Institut Kefahaman Islam Malaysia (IKIM)

[25] Norkumala Awang. (2007). Gaya Pemakanan Mempengaruhi Kesihatan Masyarakat. Kuala Lumpur: Institut Kefahaman Islam Malaysia (IKIM)

[26] Noorsalwati. (2007). Makanan dan Kesannya terhadap Pembentukan Peribadi Insan. Jurnal Majlis Islam Sarawak. Edisi Pertama. Malaysia: Malien Press Sdn. Bhd., Kuching

[27] Panduan Persatuan Pengguna Pulau Pinang (2006). Halal Haram Buku Penting Untuk Umat Islam. Pulau Pinang: Persatuan Pengguna Pulau Pinang

[28] Rushidah, Anisah dan Hazwani. (2011). Persepsi Pelajar Politeknik Terhadap Makanan Halal. Serdang: Universiti Putra Malaysia

[29] Saadan Man \& Zainal Abidin Yahaya. (2014). حلالا طبيا Halalkah Makanan Kita? Bagaimana Menanganinya di Pasaran. Kuala Lumpur: BS Print (M) Sdn Bhd

[30] Siti Norlina Muhamad, Zamzarina Che Mat@Mohd Shukor, Maznah Ali, Zulkifli Haron, Mohd Nasir Ripin, Kamarul Azmi Jasmi, \& Ahmad Kilani Mohamed. (2005). Kecenderungan Ibu bapa Muslim Terhadap Pemakanan Halal: Kajian di Skudai, Johor Bahru. Projek Penyelidikan. Pusat Pengajian Islam dan Pembangunan Sosial. Johor: Universiti Teknologi Malaysia

[31] Siti Zanariah Yusoff, Nor Azura Adzharuddin, Jusang Bolong. (2014). Faktor Pencetus Perilaku Pencarian Maklumat Produk Halal dalam Kalangan Keluarga Islam. Global Media Journal Malaysian Edition, vol 3, issue 2. Malaysia

[32] Syekh Muhammad Yusuf Qardhawi. (1980). Halal dan Haram dalam Islam. Singapura : Pustaka Nasional PTE LTD

[33] Zaidan, 'Abd al-Karim (2006). al-Wajiz fi Usul al-Fiqh. Beirut: Mua'assasah al-Risalah Nashirun.

Zaharah Hussin, Ahmad Arifin Sapat \& Ab Halim Tamuri. (2017). Pendidikan Akhlak, Analisis dan Reka Bentuk Kurikulum. Bangi: Penerbit Universiti Malaya

[34] Zakiah Samori, Amal Hayati Ishak \& Nurul Himmah Kassan. (2011). Produk Makanan Halal: Amalan Kepenggunaan Masyarakat Islam di Shah Alam, Selangor. Projek Penyelidikan. Selangor: Universiti Teknologi Mara

[35] Zakiah Samori, Amal Hayati Ishak, \& Nurul Himmah Kassan. (2014). Understanding the Development of Halal Food Standard: Suggestion for Future Research. International Journal of Social Science and Humanity, 4(6), 482-486

[36] Zulkifli Mohamad al-Bakri. (2014). Halal \& Haram dalam Islam. Negeri Sembilan: Pustaka Cahaya Kasturi SDN BHD 